\title{
PENDEKATAN KOMITMEN KERJA MELALUI PERAN GANDA DAN STRESS KERJA
}

\author{
${ }^{1}$ Dwi Astuti, \& ${ }^{2}$ Bukman Lian \\ ${ }^{1}$ Peneliti Independen Kota Palembang \\ ${ }^{2}$ Universitas PGRI Palembang \\ e-mail: 1dwiky340@gmail.com ${ }^{2}$ bukmanlian@gmail.com
}

\begin{abstract}
The problems faced by private organizations and government agencies, especially in Palembang were about the female employees who have double roles and levels of work stress they face. This is certainly a challenge for every private organization and government agencies in order to improve the quality of organizational commitment through work professionalism. Employees who have multiple roles may have severe problems, they tend to often experience work stress conflicts, because their role as an employee is difficult regardless of the role of housewife. The purpose of this research was to know the conflict of double role and level of work stress to organizational commitment to the household worker. The respondents were a housewife who works in government agencies Public Broadcaster Radio Republic Indonesia Programa 2 South Sumatera. The results of this study indicate that the increase in commitment and professionalism of work due to field work programs for employees who have double roles. Negative effects of job stress must be minimized because it can adversely affect organizational commitment. Employees who have double roles should effectively manage time to minimize work stress as a result of double roles.
\end{abstract}

Keywords: Double Role Conflict; Work Stress; Organizational Commitment; Female Employees

\section{PENDAHULUAN}

Di era Globalisasi seperti ini wanita usia produktif yang siap bekerja, adanya kesamaan gender antara wanita dan pria, sehingga membuka peluang bagi kaum wanita untuk bekerja, baik wanita yang telah berkeluarga juga telah menjadikan diri mereka sebagai sumber daya manusia yang memiliki kompetisi di dunia kerja, mereka bersaing pesat mendapat pekerjaan dan kedudukan tidak bisa di pungkiri lagi saat ini banyak karyawati yang berumah tangga baik di instansi pemerintah maupun organisasi swasta mereka bekerja dan beralasan untuk menyambung hidup keluarga mereka, karena di era globalisasi seperti ini kebutuhan hidup dan gaya hidup sangat tinggi wajar saja jika para ibu rumah tangga memilih untuk tetap bekerja guna mencukupi kebutuhan hidup dan kelangsungan hidup.

Dari data Badan Pusat statistik jumlah wanita yang bekerja di Indonesia pada tahun 2016 berjumlah 55,04 persen, dan di tahun 2017 jumlah wanita yang bekerja berjumlah sebesar 52,71 persen mengalami kenaikan 2,33 persen poin dari tahun sebelumya, dari jumlah angkatan kerja di Indonesia sendiri pada februari tahun 2017 yang berjumlah 131,55 juta orang. Ada pun jumlah penduduk yang telah bekerja di Indonesia pada tahun 2017 sebanyak 124,54 juta orang (Statistik 
Indonesia,2017). Keberhasilan suatu organisasi dan peningkatan kaum wanita yang sangat pesat di dunia kerja memang sudh bukan sebuah persoalan yang baru lagi (Anoraga, 2006). Fenomenal yang terjadi ini membuat semakin besarnya volume pekerja wanita yang menduduki jenis-jenis pekerja yang baru (Anoraga, 2014).

Salah satu peningkatan komitmen organisasi dapat dilakukan dengan cara peningkatan profesionalisme dan peningkatan kinerja mereka di dalam suatu organisasi, di mana karyawati yakin dan telah siap menerima tujuan awal yang telah dibuat oleh organisasi tersebut (Jacson, 2006). Masalah yang sering terjadi di suatu organisasi tentu memilki beberapa faktor, diantaranya usia karyawan, jabatan, gender, budaya, beban kerja karyawati, pengalaman kerja, keselarasan peran, tentu saja bagi karyawati yang memiliki peran ganda di dalam suatu organisasi baik instansi pemerintah dan swasta mereka cenderung lebih banyak memiliki permasalahan yang lebih kompleks dari pada karyawati yang belum berumah tangga.

Bagi karyawati yang telah memiliki rumah tangga, mereka tentu memiliki permasalahan yang lebih banyak di bandingkan karyawati yang belum berumah tangga atau pun karyawan pada umumnya. Bagi wanita pekerja, mereka memliki peran ganda di dalam organisasi tempat mereka bekerja dan Rumah tangga mereka, seorang ibu rumah tangga sangat sulit terlepas dari lingkungan keluarga mereka (Anoraga, 2014). Menurut Jacita (2002) pilihlah seorang wanita untuk bekerja yang memiliki landasan motif kerja sebagai berikut ini 1) Kebutuhan financial dan non financial 2) kebutuhan sosial- relasional 3) Kebutuhan aktualisasi diri dan 4) Kenyamanaan mereka dan rileks pada saat bekerja.

Seorang wanita yang bekerja menjalankan peran ganda yaitu sebagai ibu rumah tangga dan pencari nafkah bagi keluarganya, dan tugas seorang ibu rumah tangga harus mampu bertanggung jawab atas keluarganya, peran ini tentu sedikit rumit, menurut Sukmana (1995) tugas utama seorang ibu rumah tangga harus mampu mengatur tata rumah tangga dan kondisi rumah tangga harus rapi. Kondisi seperti inilah yang menjadi pemicu wanita menimbulkan konflik, ketika wanita menghadapi berbagai macam problem dalam berumah tangga hal ini menjadi pemicu penghimbas komitmen mereka terhadap organisasi tempat mereka bekerja. Konflik ini muncul di sebabkan karena akibat adanya perbedaan dan tuntunan yang mereka jalani.

Peran ini harus dimainkan secara sekaligus dalam kehidupan mereka, peran ini sering di sebut sebagai tuntutan perang ganda dan disebut sebagai konflik peran ganda dalam organisasi. Konflik sering muncul karena 
adanya perbedaan dan tuntutan yang dimainkan secara sekaligus, konflik yang akan terjadi akibat peran ganda Greenhaus dan Beutell (1985) mendefinisikan bahwa konflik peran ganda sebagai suatu bentuk konflik antara peran dimana terjadi tekanan-tekanan dari pekerjaan dan keluarga tidak memiliki kecocokan satu sama lain, serta banyaknya tugas yang saling bertentangan. Konflik perang ganda muncul pada saat seorang pekerja mengalami pertentangan antara tanggung jawab sebagai ibu rumah tangga dan tugas tugas yang ia miliki sebagai seorang karyawan yang harus dilakukannya (Munandar, 2006).

Permasalahan komitmen organisasi yang tidak terlepas dari pengaruh koflik peran ganda, dan tidak dapat terlepas dari faktor stress kerja, koflik peran ganda itu sendiri terjadi karena oleh adanya kesenjangan peran yang disebabkan karena dua peran yang bertentangan dan harus dimainkan secara bersamaan, antara lain sebagai seorang ibu rumah tangga dan peran sebagai pekerja baik dalam sebuah organisasi dan instansi pemerintah, dan pada akhirnya ibu rumah tangga sangat renta megalami stress. Kondisi ibu rumah tangga yang bekerja dan mengalami stress memiliki perbedaan stress pada pria, sehingga tidak heran jika pada saat ibu rumah tangga mengalami tekanan-tekanan tersebut dapat muncul dari dalam (internal) dan dari luar (exsternal).
Pada dasarnya setiap manusia akan cenderung mengalami stress kerja apabila mereka kurang mampung beradaptasi dengan keinginan-keinginan dan kenyataan-kenyataan yang ada, baik kenyataan itu berasal dari dalam dirinya maupun dari luar dirinya (Anoraga, 20014). Stres kerja adalah suatu kondisi dimana perasaan seseorang karyawan yang sedang mengalami tekana dalam pekerjaannya (Mangkunegara, 2013). Wijono (2010) mengatakan bahwa stress kerja karyawan disebabkan karena empat faktor utama, yaitu konflik, ketidak pastian, tekanan dari tugas serta hubungan dengan pihak manajemen.

Studi pendahuluan yang dilakukan peneliti melalui wawancara langsung dengan karyawati instasi pemerintah Lembaga Penyiar publik Radio Republik Indonesia Palembang (LPP) Programa 2, diketahui bahwa secara kasat mata cara bekerja karyawati yang berumah tangga dapat terlihat sangat berbeda. Menurut sumber yang di dapat hal ini dikarenakan adanya pelebaran tanggung jawab karyawati yang berumah tangga sehingga ada beberapa perilaku yang muncul tidak bersemangat saat bekerja, datang terlambat ke kantor dan produktivitas menurun. Menurut Puspa dan Ryanto (1999) yang mengemukakan pedapat konflik peran adalah suatu gejala phycologist yang dialami oleh setiap anggota baik organisasi dan instansi pemerintah yang dapat menimbulkan perasaan tidak nyaman 
pada saat bekerja dan secara profesionalis tentu dapat menurunkan motivasi kerja karyawati.

Pada saat tahapan wawacara langsung pertama dilakukan terhadap satu karyawati Lembaga Penyiar Publik Radio Republik Indonseia Palembang (LPP RRI) Programa 2 yang telah berumah tangga, dketahui bahwa konflik peran ganda membuat karyawati merasa memilki tuntutan tugas yang lebuh berat, tugas menjadi seorang ibu rumah tangga dan tugas bekerja sebagai karyawati yang membuat mereka merasa terbebani antara tugas dirumah tangga dan kewajiban di tempat mereka bekerja dan tahapan kedua wawancara dilakukan guna mendapatkan hasil yang lebih akurat dan meminimalkan kesalahan data dan menggali data lebih dalam dan penelitian ini menambahkan satu lagi karyawati, karyawati ini mengaku bahwa dirinya juga mengalami kondisi stress kerja, hal ini dapat terjadi pada saat intensitasi kerja di ruang lingkup tempat kerja sedang mengalami peningkatan, belum lagi tuntutan pekerjaan di rumah tangga yang harus di kerjakan, kondisi seperti inilah yang menyebabkan karyawati merasa lelah, gelisah saat berada di ruangan kerja, dan mudah marah. Berdasarkan dari uraian yang telah dijelaskan diatas maka tujuan dari penelitian ini dilakukan untuk mengetahui pendekatan antara komitmen kerja melalui peran ganda dan stress kerja.

\section{METODE PENELITIAN}

Penelitan ini adalah penelitian kualitatif. Pendekatan kualitatif concerned with process rather than simply with outcomes or product; qualitative research tend the analyze their data inductively (Kristiawan \& Tobari, 2017). Dalam penelitian ini, peneliti menggunakan teknik wawancara langsung kepada responden. Wawancara adalah proses memperoleh keterangan untuk tujuan penelitian dengan cara tanya jawab, sambil bertatap muka antara pewawancara dengan si penjawab responden dengan menggunakan alat yang dinamakan interview guide (panduan wawancara), (Nazir 2013:170). Pada penelitian ini teknik wawancara dengan menggunakan metode pendekatan penelitian membuat suatu gambaran yang lebih kompleks, meneliti berupa kata-kata, laporan yang lebih terinci dari pandangan respoden dan melakukan studi pada situasi alami Bondang dan Taylor (2007:3) mengemukakan bahwa dengan metode kualitatif merupakan prosedur penelitian yang menghasilkan data deskriptif berupa kata-kata tulisan maupun lisan dari oranng-orang yang diamati. Teknik wawancara langsung yang digunakan dalam penelitian kualitatif ini dengan wawancara mendalam untuk memperoleh keterangan untuk tujuan penelitian dengan cara Tanya jawab dan sambil bertatap muka dengan menggunakan pedoman. 
Penelitian ini dilakukan di Lembaga Penyiar publik Radio Republik Indonesia Palembang (LPP RRI) Programa 2 Sumatera Selatan yang berlokasi di Jalan Radio No.2 KM4 Palembang, Populasi dari penelitian ini adalah karyawati yang sudah berumah tangga di Lembaga Penyiar publik Radio Republik Indonesia Palembang (LPP RRI) Programa 2

\section{HASIL PENELITIAN DAN PEMBAHASAN}

Dari hasil wawancara langsung yang dilakukan tanggal 11 November 2017 kepada karyawati yang memilki Peran Ganda yang telah berumah tangga dinyatakan adanya Stress Kerja yang terjadi di Lembaga Penyiar publik Radio Republik Indonesia Palembang (LPP RRI) Programa 2 pada karyawati yang memiliki peran ganda hal ini dapat terjadi apabila karyawati memiliki tugas yang menumpuk dan tidak dapat memajemen waktu secara baik, akan tetapi pimpinan Lembaga Penyiar publik Radio Republik Indonesia Palembang (LPP RRI) Programa 2 mempunyai strategi untuk mengatasinya hal ini dilakukukan untuk meningkatan komitmen kerja melalui Konflik Peran Ganda terhadap Stress Kerja seperti melakukan Program Keja lapangan, agar para karyawati yang memiliki Peran Ganda tidak stress akibat tuntutan kerja seperti, Goes To Campus, ajang pencarian bakat, seperti bernyanyi, puisi yang diikuti oleh berbagai kalang dari mulai tingkat SMP SMA Mahasiswa di kota Palembang.

Program kerja ini dibuat guna meningkatkan profesionalisme dalam upaya pencapaian komitmen organisasi, hal ini diharapkan mampu mengurangi strees kerja para karyawati dan meningkatakkan kreatifitas karyawati yang memiliki peran ganda, dan tidak hanya itu saja peran pimpinan harus menciptakan ruang kerja yang efektif memberikan motivasi guna mengurangi stress kerja, dan Program kerja lapangan yang dilakukan oleh Lembaga Penyiar publik Radio Republik Indonesia Palembang (LPP RRI) Programa 2 ini dapat mengikat hati para pendengar setia radio, karena di era modern seperti ini radio mulai ditinggalkan kalangan muda, dengan adanya program ini masyarakat kalangan baik bawah maupun menengah dan kalangan muda tentunya mempunyai keingian untuk mendengarkan berita, music, lewat radio hal ini tentu menjadi dampak yang positif bagi RRI. Tercapaiya komitmen organisasi dengan menurunkan Stress kerja pada karyawari yang memiliki Peran Ganda adalah strategi yang dilakukan oleh Pimpinan Lembaga Penyiar publik Radio Republik Indonesia Palembang (LPP RRI) Programa 2 RRI untuk mengatasi para karyawati yang memiliki peran ganda di lingkungan organisasi.

Karyawati LPP RRI Pro 2 yang berstatus PNS harus memiliki komitmen untuk 
mencapai tujuan organisasi dan harus lebih mementingkan dinas dari pada kepetingan diri sendiri, komitmen organisasi secara umum dapat dipahami sebagai ikatan kewajiban baik karyawati yang bekerja di dalam instansi pemerintah maupun organisasi swasta, ikatan kejiwaan karyawati yang memiliki peran ganda terhadap organisasi, memiliki rasa kesetiaan dan perasaan percaya terhadap nilai-nilai yang terkandung di dalam organisasi. Komitmen ini memiliki ikatan yang sangat erat dengan integritas sehingga akan berdampak besar dalam penurunan stress kerja dan terjadi peningkatan kinerja karyawati. Apabila setiap karyawati di dalam organisasi memiliki komitmen dan loyalitas yang baik terhadap organisasi tempat mereka bekerja, maka tujuan organisasi dengan mudah dapat tercapai dari hasil penelitian yang dilakukan terhadap karyawati LPP RRI Pro 2, komitmen karyawati berada pada tahapan level yang baik, mereka memiliki integritasdan loyalitas yang baik pula, hal ini terjadi karena dapat dikatak berhasilnya program kerja lapangan yang di buat oleh pimpinan.

LPP RRI Pro 2 adalah satu satunya radio yang menyandang nama negara yang siarannya ditujukan untuk kepentingan bangsa dan negara. RRI sendiri sebagai lembaga penyiaran Publik Independen, bersifat netral dan tidak bersifat komersial, berfungsi memberikan pelayanan siaran berupa informasi, pendidikan, hiburan yang sehat, dan sosial yang sangat menjaga citra positif bangsa di dunia Internasional. Lembaga ini tidak hanya memperkerjakan tenaga kerja laki-laki namun juga banyak para karyawati yang memiliki peran ganda yang bekerja di instansi pemerintahan ini, visi program RRI Pro 2 sendiri adalah Suara Kreativitas yang didalamnya banyak melibatkan para karyawati yang memiliki peran ganda, seperti halnya kegiatan lapangan para karyawatilah yang diberikan tugas untuk membuat ide-ide kreatif untuk tercapainya komitmen organisasi.

Program ini selain dapat menurunkan stress kerja karyawati, dan mendapatkan dampak positif bagi organisasi karena melalui program ini RRI dapat merebut hati para pendengar radio di Palembang. adapun visi atau program acara siaran RRI seperti, program komedi humor, program komedi adalah suatu program yang menyajikan unsur-unsur yang menggelitik dan mengandung kelucuan secara auditif sehingga merangsang pendengar untuk tersenyum dan tertawa, sedangkan program music yang materinya mengutamakan aspek atau berkaitan dengan musik dan lagu dalam penyasian siaran kegiatan ini mendapatkan respon yang positif dikalangan masyarakat dan pemuda khususnya. Level pendengar RRI sendiri sebenarnya tidak menuntut kalangan pendengar, kegiatan sapa sahabat menjadi acara yang menarik dan ditunggu para 
pendengar radio, karena meraka dapat menyampaikan salam-salam kepada sahabatsahabat mereka dan menyapa para pendengar setia radio tentunya.

Program kuis di akhir acara baik pada saat siaran berlangsung di dalam instansi dan pada saat program kerja luar lapangan berlangsung, kuis sendiri adalah program yang materinya berupa pertanyaan teka-teki, dan permainan program ini menjadi daya tarik tersendiri bagi para pendengar. Program Goes To Campus sendiri adalah suatu program yang telah dikemas secara dinamis, dan menarik, program ini dibuat selain untuk menurunkan stress kerja karyawati yang memilik peran ganda akan, tetapi juga bertujuan memperkenalkan Sekolah-Sekolah dan Universitas di kota Palembang, dengan program ini diharapkan dapat meningkatkan karakteristik generasi muda yang memiliki moral yang tinggi, selain itu ini menjadi sarana ajang promosi tanpa biaya yang dilakukan LPP RRI Pro 2 sehingga masyaraka luas mengenal keunggulan dari masing-masing Sekolah dan Kampus yang berada di Palembang khususnya.

Kesimpulan dari hasil penelitian ini,maka dapat ditarik kesimpulan; 1) Adanya Konflik Peran ganda berpengaruh negatif terhadap karyawati yang telah berumah tangga di LPP RRI Pro 2 Palembang dan melalui Pendekatan komitmen kerja dapat menurunkan stress kerja. Hal ini membuktikan bahwa dengan adanya Pendekatan komitmen kerja yang baik dapat menurunkan tingkat stress pada karyawan. 2) Adanya Hubungan antara Stess kerja yang berpengaruh negatif terhadap karyawati yang telah berumah tangga terhadap komitmen kerja di LPP RRI Pro 2 Palembang. Hal ini dibuktikan dengan semakin rendah tingkat stress karyawati tentu sangat berdampak baik dapat meningkatkan komitmen kerja terhadap organisasi dengan menghasilkan kinerja yang semakin bagus. 3) Adanya Pedekatan Konflik Peran Ganda dan Stress Kerja terhadap Komitmen Kerja. Komitmen kerja itu sendiri dapat berpengaruh positif terhadap profesionalisme kerja karyawanti LPP RRI Pro 2 Palembang. Hal ini dapat dibuktikan dengan dilakukannya Pendekatan komitmen kerja terhadap karyawati dengan program kerja lapangan dan hasilnya dapat menurunkan stress kerja akibat tekan kerja.

Dari penelitian yang telah dilakukan terhadap karyawati yang memiliki peran ganda pada LPP RRI Pro 2 Palembang, Hasil wawancara yang dilakukan pada tanggal 11 november 2017 memperlihatkan adanya dampak negatif Stress kerja tehadap komitmen kerja karyawati yang memiliki peran ganda. Menurut Anoraga (108:2014) Stress pekerjaan adalah bagian dari stress kehidupan dan kepuasaan kerja yang dialami oleh setiap wanita karier yang memiliki peran ganda, Menurut Mayer dan allen (1991) Komitmen 
dalam berorganisasi sebagai suatu kontruktur psikologis yang merupakan karakteristik hubungan anggota organisasi denngan organisasinya dan memiliki implikasi terhadap keputusan individu utuk melanjutkan keanggotaanya dalam berorganisasi. Anggota yang memiliki komitmen terhadap organisasinya bertahap sebagai bagian dari organisasi dibandingkan anggota yang tidak memiliki komitmen terhadap organisasi. Penelitian ini didukung oleh Sri Rrosita (2012) di Asuransi Jiwa Bersama Bumiputera di Jember dan Balung dari Penelitian terdahulu yang berjudul Pengaruh Konflik Peran Ganda Terhadap Komitmen Organisasi pada Asuransi Jiwa Bersama Bumiputra 1912 di Jember.

Konflik peran ganda adalah sebuah konflik yang berasal dari pekerjaan dan keluarga. Hasil Koefisien dari pekerjaan dan keluarga. Hasil pengujian Koefisen dari analisis jalur menunjkkan bahwa konflik peran ganda berpengaruh signifikan terhadap komitmen organisasi pada Asuransi Jiwa Bersama Bumi Putera 1912. Di Cabang Jember dan Balungan dengan arah Negatif. Hal ini memiliki arti bahwa semakin rendah koflik peran ganda yang dialami oleh karyawati maka komitmen terhadap organisasi semakin tinggi.

Berdasarkan karakteristik responden diperoleh bahwa usia lebih dari 45 tahun konflik peran ganda yang dialami cukup rendah dan responden cukup memiliki komitmen terhadap organisasi. Komitmen adalah kesepakatan untuk melakukan sesuatu untuk diri sendiri, individu lain, kelompok atau organisasi, komitmen organisasi sendiri mencerminkan tingkatan keadaan di mana individu mengidentifikasikan dirinya dengan organisasi dan terikat pada tujuannya Kreitner dan Kinicki (2010:166). Sedangkan berdasarkan masa kerja lebih dari 3 tahun para karyawati kontrak (agen) di anggap telah memiliki komitmen terhadap organisasi, hal ini dibuktikan dengan mudahnya responden melakukan penyesuaian terhadap cara kerja yang diberikan oleh perusahaan, para responden selalu mendukung program kerja yang telah dibuat oleh perusahaan dengan menuangkan semua kemampuan yang mereka miliki dan para responden sudah menjadikan Asuransi Jiwa Bersama Bumiputera 1912 sebagai bagian dari hidup mereka

Dari Penelitian terdahulu yang berjudul Pengaruh Phobia Sukses Terhadap Komitmen Organisasi pada Asuransi Jiwa Bersama Bumiputra 1912 di Jember dan Cabang Balung. Phobia sukses adalah saat seseorang mendapat gangguan berupa rasa takut akan kemampuaanya menyelesaikan tugas atau pekerjaan yang menantang. Hasil pengujian koefisien dari analisis jalur, menunjukkan phobia sukses berpengaruh signifikan terhadap komitmen organisasi pada Asuransi Jiwa Bersama Bumiputera 1912 cabang Jember dan 
Balung dengan arah negatif. Hal ini memiliki arti bahwa semakin rendah phobia sukses yang dirasakan oleh karyawati maka komitmen terhadap organisasi semakin. Sebagian besar responden dengan jenjang pendidikan S1 phobia sukses, tidak meraka alami karena dengan kemampuan yang dimiliki, mereka yakin mampu mengerjakan tugasa kantornya dengan baik dan tepat waktu, sehingga waktu mereka bersama keluarga tidak berkurang.

Komitmen organisasi merupakan ukuran tentang keinginan pekerja untuk tetap dalam perusahaan di masa depan, komitmen berhubungan erat dan terikat dengan organisai di tingkat emosional. Sering mencerminkan keyakinan pekerja dalam misi dan tujuan perusahaan, keinginan, mengembangkan usaha dalam penyelesaian, dan intens melanjutkan bekerja disana. Komitmen biasanya lebih kuat di antara pekerja berjangka panjang, mereka yang mempunyai pengalaman keberhasilan personal dalam organisasi dan mereka yang bekerja dengan kelompok kerja yang mempunyai komitmen. (Newstrom, 2011: 223).

Rendahnya phobia sukses yang dirasakan oleh karyawati kontrak (agen) pada Asuransi Jiwa Bersama Bumiputera 1912 Cabang Jember dan Cabang Balung didukung oleh penelitian yang dilakukan oleh Fitria (2013) pada BPMPD Kabupaten Kampar. Rendahnya phobia sukse yang dirasakan karyawati kontrak (agen) disebabkan karena adanya keyakinan pada diri karyawati bahwa mereka mampu menjalankan kedua perannya yaitu sebagai ibu rumah tangga dan karyawati dengan baik. Adanya keyakinan yang dimiliki para karyawati ini membuat mereka optimis untuk menjadi wanita karir yang lebih sukses.

Dari penilitian terdahulu yang berjudul Stress Kerja Ditinjau dari Peran Ganda dan Dukungan Sosial pada Perawat menunjukkan bahwa adanya hubungan yang signifikan antara konflik peran ganda dan dukungan stress kerja pada perawat dengan menggunakan data statistic perawat y penelitian $\mathrm{R}=0,633:=0,400$; $\mathrm{F}=39,050 ; \mathrm{P}=0,000(\mathrm{p}<0,05)$. Hal ini bearti perawat yang memiliki konflik peran yang tinggi dan dukungan sosial yang rendah, maka tingkat stress yang dihadapi perawat tinggi. Sedangkan perawat yang memiliki konflik peran ganda yang rendah dan dukungan sosial yang tinggi, maka tingkat stress kerja yang dialami perawat rendah

Hasil Penelitian ini didukung oleh penelitian Lambert, Hogan, dan Bartosan (2004) menemukan bahwa terdapat hubungan positif dan terjadi peningkatan yang signifikan antara konflik peran ganda karyawati dan stress kerja.

Menurut Ahmad dkk (2017) dalam rangka meningkatkan dan menciptakan persaingan global, masyarakat harus memiliki kemampuan soft skill dari pada hard skill, melihat masih banyak masyarakat Indonesia 
yang lemah dibidang penguasaan soft skill, pentingya pembelajaran yang baik di jenjang pendidikan guna mempersiapkan karyawati yang siap bekerja dengan kemampuan soft skill agar dapat bersaing dengan Negara-Negara ASEAN.

Menurut Sherdan dan Radmacher (1992) Serta Gibson, dkk (1994), stress kerja dapat di pengaruhi oleh kondisi suatu organisasi, seperti halnya penetapan arah dan kebijaksanaan organisasi, perubahan terhadap strategi organisasi, dan keuangan, tuntutan kerja yang mengalami peningkatan, tanggung jawab atas pekerjaan orang lain, terjadinya perubahan waktu jam kerja, hubungan yang kurang baik dengan teman di lingkungan organisasi dan konfli peran. Akibatnya dapat menggangu konsentrasi kerja, penurunan kinerja dan individu tidak dapat memenuhi tuntutan pekerjaannya karena kurangnya dukungan sosial dari lingkugan organisasi (Luthans,1998).

Selain itu, pada penelitian terdahulu yang telah dilakukan oleh Nasir dan Nusi (2011) berpendapat bahwa terdapat suatu konflik kerja dan rumah yang memiliki pengaruh sangat besar dengan perilaku kerja karyawati dan kinerja mereka. Konflik di dalam keluarga tidak akan terjadi, apabila terjadinya keseimbangan antara peran di dalam keluarga dengan peran pekerjaan. Seorang karyawti yang telah berumah tangga yang memiliki peran ganda, selain berperan sebagai seorang istri dan ibu, dia juga berperan sebagai pencari nafkah di dalam keluarganya, Peran ganda ini sangat beresiko terjadinya konflik, sebab pada dasarnya seorang wanita lebih memprioritaskan keluarganya (suamidan anak) dari pada pekerjaannya. Hal inilah yang sering mengambat proses pencapaian kinerjanya. Konflik peran ganda yang mereka alami adalah merupakan pemicu terjadinya stress kerja.

Menurut Kristiawan (2016) Revolusi mental sangat di perlukan dalam pendidikan karakter dalam pembentukan Sumber Daya Manusia yang Pandai, untuk mewujudkan dibutuhkan komitmen dan integritas dengan menerapkan nilai-nilai kehidupan dalam pembelajaran.

Tercapainya komitmen organisasi tidak hanya dipengaruhi oleh stress kerja karyawati yang memiliki peran ganda akan tetapi, gaya kepemimpinan juga sangat berpengaruh terhadap pencapaian komitmen organisasi maupun instansi pemerintah, dan tentunya para generasi yang telah memasuki usia produktif selayaknya mendapatkan pendidikan karakter atau sering disebut revolusi mental agar tercipatanya Sumber Daya Manusia yang pandai dan berakhlak mulia. Menurut Gibson dkk, (2012:182) mengemukan pengertian tentang komitmen organisasi sebagai perasaan identifikasi, loyalitas, dan pelibatan dinyatakan oleh pekerja terhadap organisasi atau unit 
organisasi, Dukungan tempat kerja juga sangat mendukung dalam pencapaian komitme organisasi.

\section{KESIMPULAN}

Dilihat dari aspek perilaku pegawai untuk unsur orientasi dan unsur komitmen organisasai dapat dikatakan sudah berjalan maksimal, terjadinya peningkatan komitmen terhadap profesionalisme kerja dikarenakan program kerja lapangan bagi karyawati yang telah berperan ganda. Pengaruh negatif dari stres kerja harus diminimalisir karena dapat berdampak buruk terhadap komitmen organisasi. Dari unsur integritas masih dan perlu dilakukan peningkatan, hal ini karena masih banyak karyawati dan pegawai lainnya yang belum bisa memecahkan permasalahan di dalam organisasi, akan tetapi melalui program kerja lapangan diharapakan mereka dapat bekerja sama dalam menjalankan tugas di lapangan. Dilihat dari segi aspek sasaran kerja pegawai untuk unsur kualitas, kuantitas, dan efektivitas penggunaan biaya dalam organisasi ini sudah dikatakan sangat maksimal, dan karyawati yang memiliki peran ganda agar dapat manajemen waktu dengan efektif guna meminimalisir stress kerja akibat dari peran ganda.

\section{DAFTAR PUSTAKA}

Ahmad, S., Kristiawan, M., Tobari, T., \& Suhono, S. (2017). Desain Pembelajaran
SMA Plus Negeri 2 Banyuasin III Berbasis Karakter Di Era Masyarakat Ekonomi ASEAN. Iqra (Educational Journal), 2(2), 403-432.

Almasitoh, U. H. (2012). Stres kerja ditinjau dari konflik peran ganda dan dukungan sosial pada perawat. Psikoislamika Bibliography.

Anoraga, P. (2014). Psikologi Kerja. Jakarta: Rineka Cipta.

Dessler, G. (2009). Manajemen Sumber Daya Manusia. Jakarta: PT. indeks.

Indriyani, A. (2009). Pengaruh Konflik Peran Ganda Dan Stress Kerja Terhadap Kinerja Perawat Wanita Rumah Sakit (Studi Pada Rumah Sakit Roemani Muhammadiyah Semarang (Doctoral dissertation, Program Pascasarjana Universitas Diponego

Izzah, K., Wahyu Lelly H S, S., \& Desia Prajitiasari, E. (2015). Pengaruh Konflik Peran Ganda dan Phobia Sukses Terhadap Kinerja Karyawati Kontrak (Agen) Melalui Komitmen Organisasi Pada Asuransi Jiwa Bersama Bumiputera 1912 Cabang Jember dan Cabang Balung.

Kristiawan, M. (2016). Telaah Revolusi Mental Dan Pendidikan Karakter Dalam Pembentukan Sumber Daya Manusia Indonesia Yang Pandai Dan Berakhlak Mulia.

Kristiawan, M. (2017). The Characteristics of the Full Day School Based Elementary School. Transylvanian Review, 1(1).

Nazir, M. (2014). Metode Penelitian. Bogor: Ghalia Indonesia.

T.Sulistiyani, A. (2003). Manajemen Sumber Daya Manusia. Yogyakarta : Graha Ilmu. 
Wibowo. (2014). Manajemen Kinerja Edisi

Keempat. Jakarta: PT. RajaGrafindo

Persada. 